\title{
HIGH PREVALENCE OF CLASS I AND CLASS II INTEGRONS IN UROPATHOGENIC E. COLI STRAINS (UPECS) AND THEIR RELATIONSHIP WITH ANTIBIOTIC RESISTANCE, PHYLOGENY AND VIRULENCE
}

\author{
ÜROPATOJEN E. COLI (UPEC) SUŞLARINDA SINIF I VE SINIF II INTEGRONLARIN \\ YÜKSEK PREVALANSI ILE ANTIBIYOTIK DIRENCI, FILOGRUP VE VIRULANS ILIŞKISI
}

\author{
Defne GÜMÜŞ ${ }^{1}$ (D), Fatma KALAYCI YÜKSEK ${ }^{1}$, Firdevs Deniz CAMADAN² (D), Merve ORAL² (D), \\ Aslı Ceren MACUNLUOĞLU ${ }^{3}$, Mine ANĞ KÜÇÜKER ${ }^{1}$ (D) \\ 1'istanbul Yeni Yüzyıl University, Faculty of Medicine, Department of Medical Microbiology, İstanbul, Turkey \\ ${ }^{2}$ Istanbul Yeni Yüzyıl University, Faculty of Arts and Science, Department of Molecular Biology and Genetics, İstanbul, Turkey \\ ${ }^{3}$ Uludağ University, Institute of Health Sciences, Department of Biostatistics, Bursa, Turkey
}

ORCID IDs of the authors: D.G. 0000-0003-4070-6924; F.K.Y. 0000-0002-0028-5646; F.D.C. 0000-0003-3057-6038; M.O. 0000-0002-7510-8441; A.C.M. 0000-0002-6802-5998; M.A.K. 0000-0002-4809-3985

Cite this article as: Gumus D, Kalayci Yuksek F, Camadan FD, Oral M, Macunluoglu AC, Ang Kucuker M. High prevalence of class I and class II integrons in uropathogenic E. coli strains (UPECS) and their relationship with antibiotic resistance, phylogeny and virulence. J Ist Faculty Med 2022;85(1):77-85. doi: 10.26650/IUITFD.984487

\section{ABSTRACT}

Objective: Integrons, which are highly effective in capturing, integrating and expressing gene cassettes, play an important role in the dissemination of multiple antibiotic resistances. This study investigated the correlations of integrons in uropathogenic E. coli (UPEC) with antibiotic resistance, virulence and phylogeny and also the relationships of phylogroups with virulence and antibiotic resistance.

Materials and Methods: Fifty UPECs isolated from uncomplicated cystitis and uncomplicated pyelonephritis were investigated to detect the presence of class I, II and III integrons and phylogenetic grouping by the PCR method. Their statistical relationship with antibiotic resistance and virulence genes were investigated using our previous findings.

Results: Among 50 UPEC strains, 37 (74\%), 22 (44\%) and only one (2\%) strain was shown to harbor class I, class II and class III integrons, respectively. Twenty one (42\%) strains were found to carry both class I and class II integrons. The majority of the strains were grouped as phylogroup B2 (38\%) and phylogroup E (38\%). The presence of integrons was in association with only ampicillin resistance ( $p=0.014)$. Integrons was found to be related neither to virulence genes nor phylogroups; however, the presence of PAl $(p<0.001)$, ompT $(p=0.035)$, and usp $(p<0.001)$ genes was found

\section{ÖZET}

Amaç: Gen kasetlerinin yakalanması, integrasyonu ve ekspresyonunda oldukça etkin olan integronlar, çoğul antibiyotik direncinin yayılımında önemli bir rol oynarlar. Bu çalışmada, üropatojen E. coli (UPEC) suşlarında integron varlığının antibiyotik direnci, virülans ve filogenetik gruplar ile ve filogrupların, virulans ve antibiyotik direnci ile ilişkisi araştırılmıştır.

Gereç ve Yöntemler: Komplike olmayan sistit ve komplike olmayan piyelonefrit etkeni olarak izole edilen 50 UPEC suşu sınıf I, II ve III integronların varlığı ve filogruplarının belirlenmesi amacıyla PCR yöntemi ile incelenmiştir. Elde edilen sonuçlar istatistiki ilişki açııından daha önceki araştırmamızdan elde ettiğimiz bulgular ile incelenmiştir.

Bulgular: Elli UPEC suşunun 37'sinin (\%74) sınıf I integron, 22'sinin (\%44) sınıf II integron ve bir suşun (\%2) ise sınıf III integron taşıdığı belirlenmiştir. Yirmi bir (\%42) suşun ise sınıf I ve sınıf ॥ integronları birlikte taşıdığı gösterilmiştir. Suşların çoğu B2 (\%38) ve E (\%38) filogruplarında sınıflandırılmıştır. İntegronların varlığı ile sadece ampisilin direnci ilişkili bulunmuştur $(p=0,014)$. Integronların varlığı ile virulans genleri veya filogruplar arasında bir ilişki bulunmamıştır; ancak PAl $(p<0,001)$, ompT $(p=0,035)$ ve usp $(p<0,001)$ genlerinin varlığı ile B2 filogrubu arasında anlamlı ilişkili bulunmuştur. Filogrup E ile ko-trimoksazol direnci arasında

Corresponding author/illetişim kurulacak yazar: defne.gumus@yeniyuzyil.edu.tr

Submitted/Başvuru: 14.04.2021 • Revision Requested/Revizyon Talebi: $01.06 .2021 \bullet$

Last Revision Received/Son Revizyon: 02.07.2021 • Accepted/Kabul: 10.08.2021 • Published Online/Online Yayın: 12.01 .2021 
to be significantly related to phylogroup B2. Phylogroup E was found to be statistically significantly correlated with co-trimoxazole resistance $(p=0.043)$.

Conclusion: Consistent with previous studies, our results have proven that there is a strong association between antibiotic resistance and the presence of integrons (especially class I) in UPEC strains, and it has been shown that integrons became very prevalent globally.

Keywords: Uropathogenic E. coli, phylogroups, integrons, virulence factors, antibiotic resistance anlamlı ilişkili bulunmuştur $(p=0,043)$.

Sonuç: Bulgularımız literatürle de uyumlu olarak UPEC suşlarında antibiyotik direnci ile integronların (özellikle sınıf I) varlığı arasında güçlü bir ilişki olduğunu kanıtlamış ve tüm dünya genelinde integronların yaygın görüldüğü anlaşılmıştır.

Anahtar Kelimeler: Üropatojen E. coli, filogruplar, integronlar, virulans faktörleri, antibiyotik direnci

\section{INTRODUCTION}

Over the last decades, investigations have shown that integrons are highly effective in capturing, integrating and expressing gene cassettes, and play an important role in the dissemination of multiple antibiotic resistances within microbial populations. Integrons lack the specific mobilization machinery, but they are associated with insertion sequences, transposons and/or plasmids (1-4).

Integrons have an integrase gene (intl), an attachment site (attl), and a promoter region ( $\mathrm{Pc}$ ) which induces the expression of integrated gene cassettes (1, 5-7). Among the five different classes of integrons, class I and class II integrons are the most common and clinically important. Integrons are very common (22-95\%) in enteric bacteria isolated from various infections, although they are also found to be present in commensal bacteria. Studies have shown that integrons horizontally transfer more than 130 different gene cassettes, which encode antibiotic resistance $(8,9)$.

Escherichia coli are classified into different pathogenicity groups according to specific virulence factors. One of these pathogroups is known as uropathogenic E. coli (UPEC). As one of the primary etiological agents of urinary tract infections (UTIs), UPECs account for $80-90 \%$ cases of community-acquired UTIs and $40-50 \%$ of hospital-acquired UTIs. It is well known that UTIs are one of the most common infectious diseases, with nearly 150 million new cases diagnosed annually all around the world (7, $10,11)$. It has been shown that UPEC is a heterogeneous group of strains composed of several virulence assortments and phylogroups. The majority of various virulence traits of UPECs are fimbrial and/or afimbrial adhesins, iron uptake systems such as siderophores, exotoxins and bacteriocins (12-16).

According to the presence/absence of chuA and yjaA and DNA fragment TspE4.C2, E. coli strains are classified into four main phylogroups (A, B1, B2 or D) (17); however in the last decade four new phylogroups were identified which have caused $E$. coli strains to be classified into eight groups (A, B1, B2, C, D, E, F and Escherichia clade I) (18). Previous studies have shown that UPECs are mostly grouped as phylogenetic groups B2 and D, and virulence factors described for UPECs are shown to be related to phylogenetic group B2 $(6,7,19)$.

This study investigated the correlations of integrons in UPECs with antibiotic resistance, virulence and phylogeny and also the relationship between phylogroups and virulence.

\section{MATERIALS AND METHODS}

\section{Strains}

Fifty UPEC strains isolated from patients with different uncomplicated cystitis and uncomplicated pyelonephritis were included. These strains were isolated within the context of our previous study in which their virulence genes (afa, aer, cnf1, sfa/foc, pap3/4, PAl, iroN, ompT, hly, usp, pap 1/2) and antibiotic susceptibilities [ampicillin (AMP), amoxicillin/clavulanate (AMC), cefuroxime (CXM), ceftriaxone $(C R O)$, cefixime (CFX), gentamicin $(G N)$, ciprofloxacin (CIP), ofloxacin (OFX), co-trimoxazole (SXT), nitrofurantoin (NIT) and aztreonam (ATM)] were investigated back then (15). We kept the bacteria at $-80^{\circ} \mathrm{C}$ for further examinations.

\section{Detection of integrons and phylogroups}

The DNA template from UPECs was prepared from overnight cultures in Tryptic soy broth (TSB) at $37^{\circ} \mathrm{C}$. An extraction kit (GeneDireX, Taiwan) was used according to the manufacturer's instructions.

We investigated the presence of class I, class II and class III integrons on both genomic and plasmid DNAs as suggested in Ren et al. (20). For this purpose, all extracted DNAs were examined by multiplex polymerase chain reaction (PCR) for the presence of intl, intll and int III genes (20).

Primers used in this research are shown in Table 1 (20, 21). A master mix kit (Genemark, Taiwan) was used in PCR assays. Mixtures ( $25 \mu \mathrm{L}$ last volume) were prepared according to the manufacturer's suggestions (Genemark, Taiwan): $5 \mu \mathrm{L}$ master mix, $2 \mu \mathrm{L}$ DNA, $2 \mu \mathrm{L}$ each primer ( $1 \mu \mathrm{L}$ for each primer from 10 pmol concentration) and nuclease-free water. 
Table 1: Primers used in integron PCR analysis

\begin{tabular}{llcc}
\hline Genes & Primer sequence & Amplicon size & Reference \\
Class I int F & 5'-CCT CCC GCA CGA TGA TC-3' $^{\prime}$ & $280 \mathrm{bp}$ & $(20,21)$ \\
Class I int R & 5'-TCC ACG CAT CGT CAG GC-3' $^{\prime}$ & \\
Class II int F & 5'- GTA GCA AAC GAG TGA CGA AAT G-3' $^{\prime}$ 780 bp \\
Class II int R & 5'-CAC GGA TAT GCG ACA AAA AGG T-3' & \\
Class III int F & 5' -GCC TCC GGC AGC GAC TTT CAG-3' & 976 bp \\
Class III int R & 5'-ACG GAT CTG CCA AAC CTG ACT-3' & & \\
\hline
\end{tabular}

The reaction conditions for PCR amplification were as follows: initial denaturation for 4 min at $94^{\circ} \mathrm{C}$; degradation for $45 \mathrm{sec}$ at $94^{\circ} \mathrm{C}$; annealing for $45 \mathrm{sec}$ at $57^{\circ} \mathrm{C}$; elongation for $55 \mathrm{sec}$ at $72^{\circ} \mathrm{C}$; final elongation for 4 min at $72^{\circ} \mathrm{C}$. These reactions were carried out for 30 cycles (Prima Trio high media thermal cycler, Mumbai, India) (20). The amplicons were stored at $-20^{\circ} \mathrm{C}$.

We could not find any strain harboring intlll gene for use as a positive control in PCR assays. Therefore, DNA sequence analysis was performed for confirmation of class III integron positive DNA samples by using the ABI3730 XL Genetic Analyzer device (GATC Biotech AG, Germany).

According to the study of Clermont et al., (18), phylogroups of UPEC strains were determined via two sequential PCR assays. In the first stage, phylogroups were determined according to the presence/absence of TspE4.C2, chuA, yjaA and arpA genes. Second multiplex PCR assays using trpAgpC, ArpAgpE, and trpBA primers were performed to distinguish the phylogroups $D$ from $E$ E from Escherichia clade I, and A from C (18). All primers are shown in Table 2.

A Master mix kit (Genemark, Taiwan) was used in PCR. Mixtures ( $25 \mu \mathrm{L}$ last volume) were prepared according to the manufacturer's suggestions (Genemark, Taiwan): $5 \mu \mathrm{L}$ master mix, $2 \mu \mathrm{L}$ DNA, $2 \mu \mathrm{L}$ each primer $(1 \mu \mathrm{L}$ for each primer from 10 pmol concentration), and nuclease-free water.

The reaction conditions for PCR amplification were as follows: initial denaturation for $4 \mathrm{~min}$ at $94^{\circ} \mathrm{C}$; degradation for $30 \mathrm{sec}$ at $94^{\circ} \mathrm{C}$; annealing for $30 \mathrm{sec}$ at $56^{\circ} \mathrm{C}$; elongation for $45 \mathrm{sec}$ at $72^{\circ} \mathrm{C}$; final elongation for $5 \mathrm{~min}$ at $72^{\circ} \mathrm{C}$. These reactions were carried out for 30 cycles (Prima Trio high media thermal cycler, Mumbai, India) (18). The amplicons were stored at $-20^{\circ} \mathrm{C}$.

All amplified products were separated by agarose gel electrophoresis in a 1.5\% agarose gel stained with ethidium bromide $(0.5 \mu \mathrm{g} / \mathrm{mL})$, visualized under UV light. After that products were electrophoresed for 40 min under 80

Table 2: Primers used in phylogroup PCR analysis

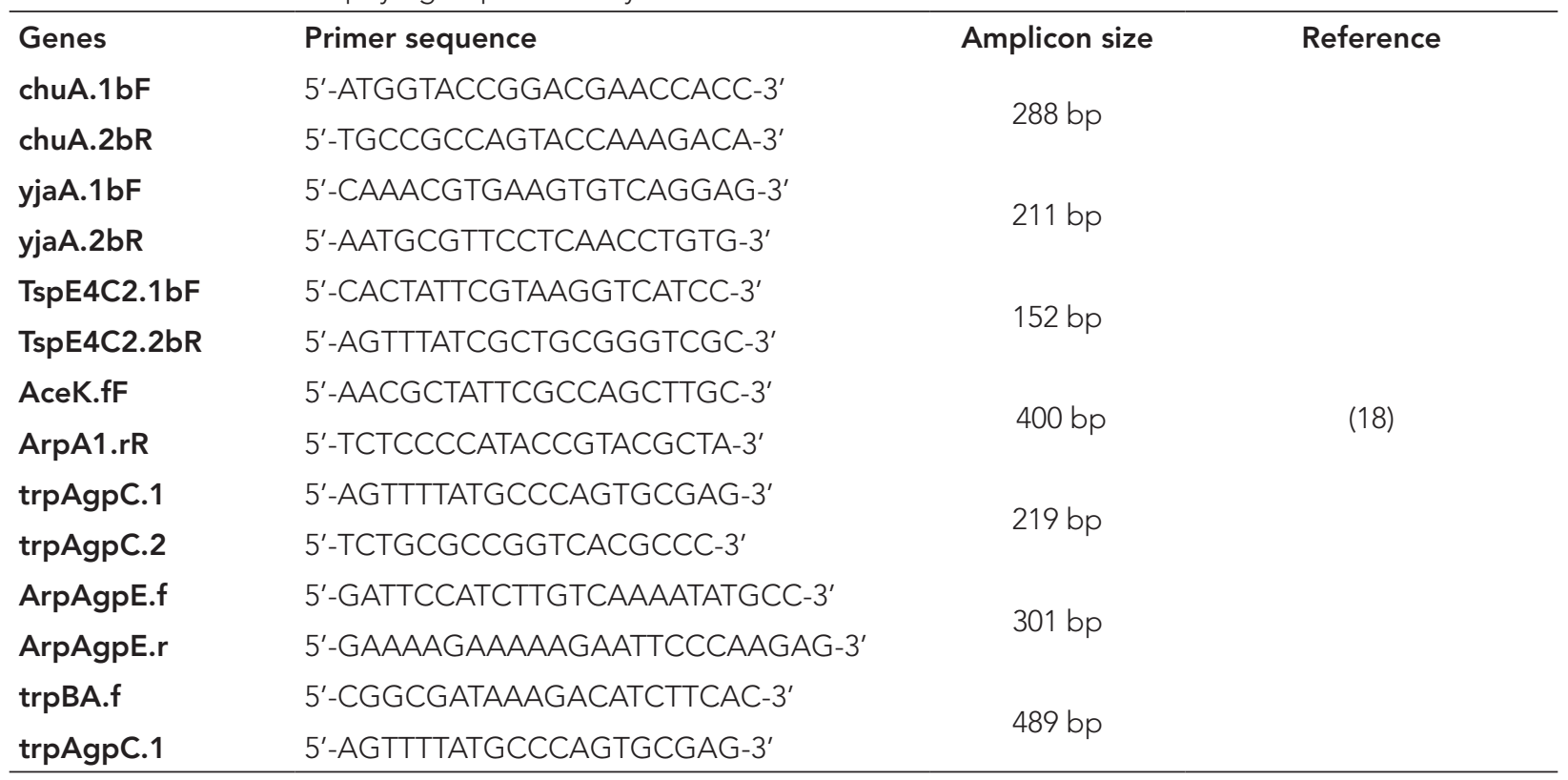


volts with 1XTBE electrophoretic liquid. The results were visualized and recorded using Hi-UV MAX transilluminator (HiMedia, India). DNA ladder (Genemark, Taiwan) labeled between 100-1000 bp was used.

\section{Statistical analysis}

The correlations of integrons with antibiotic resistance, virulence genes, and phylogroups were statistically analyzed. The categorical variables were reported as $n$ (\%) by using the Pearson Chi-Square test, and Fisher's exact test. SPSS (IBM Corp. Released 2012. IBM SPSS Statistics for Windows, Version 21.0, Armonk, NY: IBM Corp.) was used for statistical analysis, and a p-value $<0.05$ was considered as statistically significant.

This study was approved by the Istanbul Yeni Yuzyıl University Medical Faculty Research Ethics Committee (Date: 01.10.2018, No: 8).

\section{RESULTS}

\section{Detection of integrons}

Among 50 UPEC strains, 37 (74\%) and 22 (44\%) were shown to carry class I and class II integrons, respectively. Twenty-one (42\%) of UPECs were found to possess both classes I and II integrons (Figure 1-2).

It was also shown that both intl and intll genes were encoded more frequently in plasmids rather than genomic DNA. The intl gene was shown to be harbored in 22 (44\%) strains on genomic DNA and in 34 (68\%) strains on plasmid DNA. Similarly, 14 (28\%) and 19 (38\%) of UPEC strains were found to possess intll genes in genomic and plasmid DNA, respectively. We found that only one strain was shown to carry the intIll gene which was encoded only on plasmid DNA. The result was confirmed with a sequence analyzing method.

\section{Detection of phylogroups}

The majority of the strains were grouped as phylogroup B2 (38\%) and phylogroup E (38\%), and the rest of the

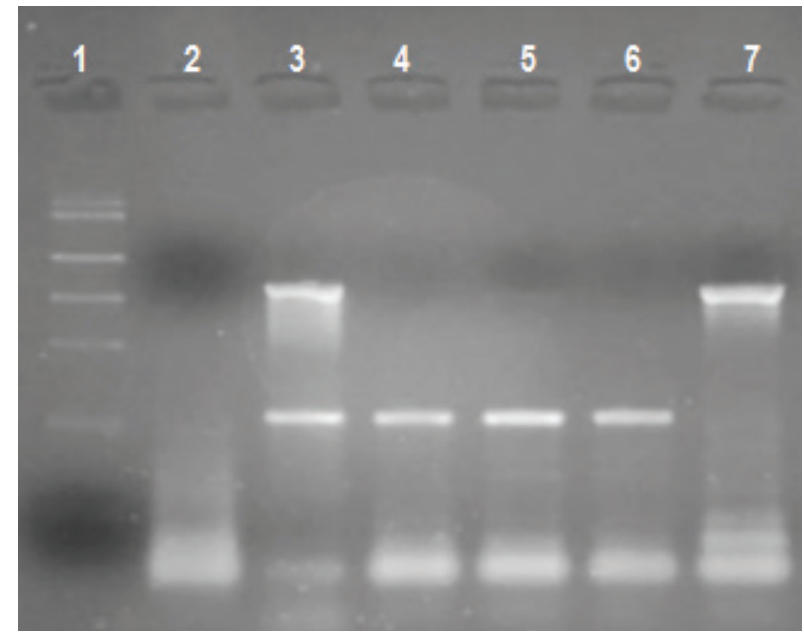

Figure 1: Agarose gel image of the intl and intll genes amplified by multiplex PCR

Well 1: DNA ladder, well 2: negative control, well 3: positive control (intl-280 bp and intll-780 bp), well 4-6: intl positive strains, well 7: intll positive strains

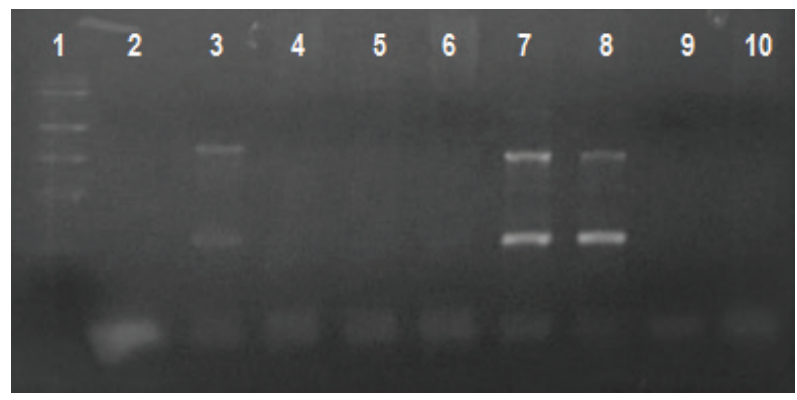

Figure 2: Agarose gel image of the intl and intll genes amplified by multiplex PCR

Well 1: DNA ladder, well 2: negative control, well 3: positive control (intl-280 bp and intll-780 bp), well 4-6: negative strains, well 7-8: intl and intll positive strains

strains were defined as D (8\%), A (2\%), C (2\%) and F (2\%). Five (10\%) strains could not be classified (Figure 3 and 4).

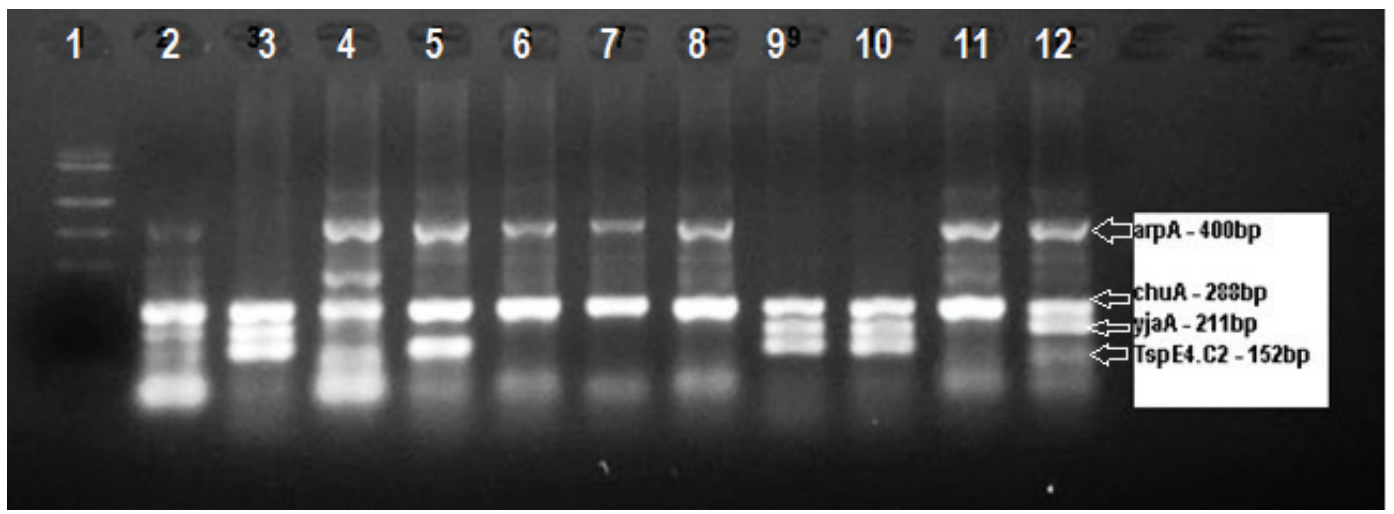

Figure 3: Agarose gel image of the arpa, chuA, yjaA and TspE4.C2 genes amplified by the multiplex PCR. Well 1: DNA ladder, well 2: positive control, well 3: group B2, well 4-8: group E, well 9-10: group B2, well 11-12: group E. 


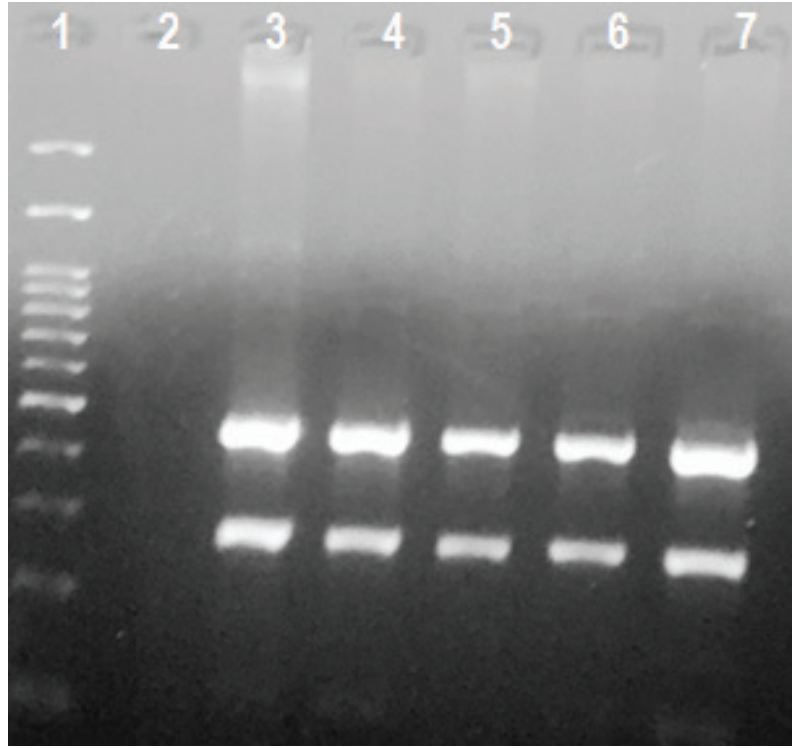

Figure 4: Agarose gel image of the multiplex PCR assays used for detection of E/cladel groups.

Well 1: DNA ladder, well 2: negative control, well 3-7: trpBA (489 bp) and ArpAgpE (301 bp) positive strains which are classified as group $\mathrm{E}$.

\section{Statistical analysis}

A statistically significant correlation $(p=0.014)$ of the presence of integrons was found only to ampicillin resistance (Table 3).

In integron-bearing strains, the rate of the usp gene was shown to be lower than non-integron bearing strains and the difference was statistically significant $(p=0.013)$ (Table 4). There was no statistically significant relationship between the presence of integrons and other virulence genes $(p>0.05)$.

There was no statistically significant $(p>0.05)$ relation between the presence of integrons and phylogroups.

Statistically significant relations between virulence genes and phylogroups were as follows: the presence of PAI $(p<0.001)$, ompT $(p=0.035)$, and usp $(p<0.001)$ genes were higher in group B2. The presence of $s f a / f o c, P A l$ and usp genes were found to be lower $(p=0.035, p<0.001$ and $p<0.001$, respectively) and the omp $T(p=0.013)$ gene was higher in the $\mathrm{E}$ phylogroup than the others.

Only resistance to SXT was found to be statistically significantly $(p=0.043)$ related to group $E$.

\section{DISCUSSION}

In the present study, 50 UPEC strains isolated from acute uncomplicated cystitis and acute uncomplicated pyelonephritis patients were investigated to determine the relations

Table 3: Correlation between integrons and antibiotic resistance

\begin{tabular}{|c|c|}
\hline $\begin{array}{l}\text { Integron } \\
\text { positive } \\
(n=38)\end{array}$ & $\begin{array}{c}\text { Integron } \\
\text { negative } \\
(n=12)\end{array}$ \\
\hline
\end{tabular}

\section{AMP}

$\mathrm{S} \quad 3(7.89 \%) \quad 5(41.67 \%)$

$0.014^{a}$

$\mathrm{R}$

$35(92.11 \%) \quad 7(58.33 \%)$

SXT

$\mathrm{S}$

$20(52.63 \%) \quad 10(83.33 \%)$

$\mathrm{R}$

$18(47.37 \%) \quad 2(16.67 \%)$

$0.091^{a}$

CIP

$\mathrm{S}$

$\mathrm{R}$

$28(73.68 \%)$

$11(91.67 \%)$

$1(8.33 \%)$

$0.257^{a}$

AMC

$\begin{array}{lll}S & 30(78.95 \%) & 9(75 \%) \\ R & 8(21.05 \%) & 3(25 \%)\end{array}$

$>0.99^{a}$

\section{OFX}

\section{$\mathrm{S}$}

$\mathrm{R}$

CFX

$S$

$\mathrm{R}$

ATM

$\begin{array}{ccc}S & 33(86.84 \%) & 12(100 \%) \\ R & 5(13.16 \%) & 0(0 \%)\end{array}$

\section{CXM}

$$
\mathrm{S}
$$

$\mathrm{R}$

$\begin{array}{cc}34(89.47 \%) & 12(100 \%) \\ 4(10.53 \%) & 0(0 \%)\end{array}$

$0.560^{\circ}$

CRO

$$
S
$$

$\mathrm{R}$

$34(89.47 \%)$
$4(10.53 \%)$

$12(100 \%)$

$0(0 \%)$

$0.560^{a}$

NIT

$\begin{array}{ccc}\mathrm{S} & 34(89.47 \%) & 12(100 \%) \\ \mathrm{R} & 4(10.53 \%) & 0(0 \%)\end{array}$

GN

\begin{tabular}{cccc}
$\mathrm{S}$ & $36(94.74 \%)$ & $12(100 \%)$ & $>0.99 \mathrm{a}$ \\
$\mathrm{R}$ & $2(5.26 \%)$ & $0(0 \%)$ & \\
\hline
\end{tabular}

Data are expressed as $\mathrm{n}(\%)$, a: Fisher's Exact Test, S: susceptible, R: resistant

of integron classes (I-III) with antibiotic resistance, virulence genes and phylogeny. Moreover, the correlation of phylogeny, virulence and antibiotic resistance was also examined. 
Table 4: Correlation between integrons and virulence genes

\begin{tabular}{|c|c|c|c|}
\hline & $\begin{array}{l}\text { Integron } \\
\text { positive } \\
(n=38)\end{array}$ & $\begin{array}{c}\text { Integron } \\
\text { negative } \\
(n=12)\end{array}$ & p-value ${ }^{a}$ \\
\hline \multicolumn{4}{|l|}{ afa } \\
\hline positive & 2 (5.26\%) & $0(0 \%)$ & \multirow{2}{*}{$>0.99^{a}$} \\
\hline negative & 36 (94.74\%) & 12 (100\%) & \\
\hline \multicolumn{4}{|l|}{ aer } \\
\hline positive & 19 (50\%) & $5(41.67 \%)$ & \multirow{2}{*}{$0.614^{b}$} \\
\hline negative & 19 (50\%) & 7 (58.33\%) & \\
\hline \multicolumn{4}{|l|}{ cnf1 } \\
\hline positive & 8 (21.05\%) & 4 (33.33\%) & \multirow{2}{*}{$0.448^{a}$} \\
\hline negative & 30 (78.95\%) & $8(66.67 \%)$ & \\
\hline \multicolumn{4}{|l|}{$s f a / f o c$} \\
\hline positive & 7 (18.42\%) & 4 (33.33\%) & \multirow{2}{*}{$0.424^{a}$} \\
\hline negative & 31 (81.58\%) & 8 (66.67\%) & \\
\hline \multicolumn{4}{|l|}{ pap $^{3 / 4}$} \\
\hline positive & 1 (2.63\%) & 1 (8.33\%) & \multirow{2}{*}{$0.426^{a}$} \\
\hline negative & 37 (97.37\%) & 11 (91.67\%) & \\
\hline \multicolumn{4}{|l|}{ iroN } \\
\hline positive & 14 (36.84\%) & $5(41.67 \%)$ & \multirow{2}{*}{$>0.99^{a}$} \\
\hline negative & 24 (63.16\%) & 7 (58.33\%) & \\
\hline \multicolumn{4}{|l|}{ PAI } \\
\hline positive & 17 (44.74\%) & 8 (66.67\%) & \multirow{2}{*}{$0.185^{b}$} \\
\hline negative & 21 (55.26\%) & 4 (33.33\%) & \\
\hline \multicolumn{4}{|l|}{ ompT } \\
\hline positive & 29 (76.32\%) & 10 (83.33\%) & \multirow{2}{*}{$>0.99^{a}$} \\
\hline negative & 9 (23.68\%) & 2 (16.67\%) & \\
\hline \multicolumn{4}{|l|}{ hly } \\
\hline positive & 2 (5.26\%) & 2 (16.67\%) & \multirow{2}{*}{$0.240^{\mathrm{a}}$} \\
\hline negative & 36 (94.74\%) & 10 (83.33\%) & \\
\hline \multicolumn{4}{|l|}{ usp } \\
\hline positive & 16 (42.11\%) & 10 (83.33\%) & \multirow{2}{*}{$0.013^{b}$} \\
\hline negative & 22 (57.89\%) & $2(16.67 \%)$ & \\
\hline \multicolumn{4}{|l|}{ pap $1 / 2$} \\
\hline Positive & 17 (44.74\%) & 7 (58.33\%) & \multirow{2}{*}{$0.411^{b}$} \\
\hline Negative & 21 (55.26\%) & 5 (41.67\%) & \\
\hline
\end{tabular}

Data were expressed as $n(\%)$, a: Fisher's Exact Test, b: Pearson Chi-Square Test

Previous studies investigating the presence of bacterial integrons were mainly reported in various clinical isolates from Iran. Farshad et al. have shown that the prevalence of class I and class II integrons in strains isolated from urine samples of children were $6.25 \%$ and $10.4 \%$ respectively, and the class III integron was not detected (22). In another study from Iran, Falakian et al. reported that the prevalence of class I integrons was $49 \%$ in UPEC strains (10). The frequency of class I and class II integrons in UPEC strains were reported as $52 \%$ and $2.5 \%$, respectively, by Khoramrooz et al. (5). Class III integron was not found in any of the isolates. They also showed a strong relationship between the presence of integrons and resistance to co-trimoxazole, ciprofloxacin, ceftazidime, and tetracycline resistance rates (5). Ebrahim-Saraie et al. reported that the prevalence of class I and class II integrons were $59.5 \%$ and $7.4 \%$, respectively, in UPEC strains. While in the same study no class III integron was detected, resistance to sulfonamides and the presence of class I integron was found to be statistically related (2). In a study of Mirnezami et al. the prevalence of integrons in 100 UPEC strains were found to be $70 \%$ and $3 \%$ for class I and class II integrons, respectively. They also reported a strong relationship between the presence of class I integron and resistance to ampicillin, gentamicin, ciprofloxacin, co-trimoxasole, and nalidixic acid (23). Similar to previous studies, our study has shown that there was a high frequency of class I (74\%) and class II integrons (44\%). Also, the class III integron was detected in one of the UPEC strains.

In a study by El-Najjar et al. in Lebanon, it was shown that $30 \%$ of UPEC strains were positive for the class I integron. They also indicated that the prevalence of antibiotic resistance rates was higher in integron harboring strains (4). In Syria, Al-Assil et al. detected that $54.6 \%$ of UPEC strains harbored class I integrons and there was a strong correlation between multidrug resistance and class I integrons (24).

In a study from the USA, Solberg et al. reported that the detection rates of class I and class II integrons were 49\% and $20 \%$, respectively, in UPEC strains (25). Solberg et al. have declared a high prevalence rate of class II integrons when compared to the studies mentioned above. However, our results have shown a higher detection rate $(44 \%)$ of class II integrons. In the study of Zeighami et al., $92.5 \%$ of UPEC and diarrheagenic E. coli strains (DEC) were found to carry integrons; the prevalence of class I and class II integrons were reported to be $85 \%$ and $2 \%$, respectively. Class III integrons were not detected. As compared to UPEC, DEC was reported to carry integrons more frequently (94\% for class I, 8\% for class II) and they emphasized that enteric pathogens could act as a reservoir or donor of several antibiotic resistance genes which can be transferred to other E. coli pathogroups (26). Ochoa et al. in Mexico, have shown that class I and class II integron rates in multi-drug resistant (MDR) UPEC strains were $44 \%$ and $2 \%$, respectively. They also showed that $48 \%$ and $9.5 \%$ of extended-drug resistant (XDR) UPECs 
harbored class I and class II integrons, respectively, and none of these strains carried class III integron (7).

As seen above, the majority of the studies are mainly from the Middle-East (especially from Iran) and have shown higher frequencies of integrons. However, in a meta-analysis study, Halaji et al. emphasized that there is a strong correlation between class I integrons and high-level antibiotic resistance. In the same study, two issues were emphasized: firstly, the majority of the strains harbored class I integron isolated from hospital-acquired UTIs; and secondly, the frequency of class I integron carrying strains are high in Middle Eastern countries (27). Studies investigating the presence of integrons and their relation with antibiotic resistance in UPEC strains are limited in Turkey. In a multi-centered study, Çopur-Çiçek et al. reported that the prevalence of class I and class II integrons were $26 \%$ and $17 \%$, respectively (28).

Numerous studies have examined the relationship between the presence of integrons, antibiotic resistance and phylogeny in E. coli. In a study by Poey and Lavina from Uruguay, UPEC strains isolated from pregnant women and children with urinary tract abnormalities were examined. The prevalence rates of class I and class II integrons were reported to be $22 \%$ and $8 \%$, respectively. They have shown that the proportion of integron bearing strains were higher in children with urinary tract abnormalities due to recurrent antibiotic treatments. Resistance to ampicillin, cephalotin, and co-trimoxazole was found to be significantly associated with the presence of integrons. They also found a strong correlation between class I integron and phylogroup D (6). A similar approach was carried out by Oliveira-Pinto et al. from Brazil. They compared the presence of class I integrons in strains isolated from feces of healthy individuals who did not use any antibiotics and urine of women with community-acquired UTIs. They showed a higher incidence of class I integron in E. coli strains isolated from urine (65\%) than commensal E. coli strains (12\%); only urine strains were shown to be multi-resistant to all antibiotics tested. Most of the urine strains were grouped in phylogroup B2, however, $43 \%$ of commensal strains were shown to be assigned in phylogroup A (9). Gündoğdu et al. reported that the prevalence of class I and class II integrons were found to be $34.3 \%$ and $5.1 \%$, respectively, and class III integrons were not detected in UPEC strains isolated from hospitalized patients in Austria. The prevalence of multi-drug resistance was shown to be significantly higher among integron positive strains and the majority (78\%) of the strains were assigned to phylogroup B2 (29). Yekani et al., in Azerbaijan, showed that class I and class II integrons were found to be harbored in $64 \%$ and $4.5 \%$ of UPECs, respectively, and class III integrons were not found. The authors suggested that multi-drug resistance was significantly associated with the presence of class I integrons. Although strains were mostly shown to be assigned to phylogenetic group B2 (61\%), a high prevalence of class I and class II integrons were detected among group B1 strains (3). In another study from Mexico examining multi-drug resistant UPECs, it was reported that class I integrons were distributed in phylogenetic groups A, B2, and D (40\%, 44\%, and 44\%, respectively); class 2 integrons were distributed in phylogenetic groups B2 and D (3\% and 2\%, respectively) (7). Olivera-Pinto et al. from Brazil showed that $55 \%$ of UPEC isolates belonged to phylogroup B2, and to a lesser extent to group D, whereas most commensal E. coli isolates were grouped in phylogroup A (43\%) (9). It seems that the presence of integrons is shown to be statistically significantly related to phylogroups B1, B2 and D in UPECs $(3,6,9,29)$.

In our study, $74 \%$ of the UPECs were shown to carry class I and/or class II. Furthermore, we found that the integrons were encoded mostly on plasmids. Previous studies have clearly shown that the presence of integrons is associated with particular multi-drug resistance patterns; in our study, the presence of integrons and ampicillin resistance were found to be correlated. According to our results, it was shown that the majority of the UPECs were distributed equally in groups B2 (38\%) and E (38\%). However, we did not find any statistically significant relationship between the presence of integrons and phylogroups. The phylogroup E and resistance to SXT were shown to be statistically correlated.

The limited number of studies showed the possible relations between the presence of integron and virulence factors. Poey and Lavina showed that class I integrons were found to take part in strains that carry $P$ fimbria, yersiniabactin, and aerobactin systems (6). Düzgün et al. reported that there was a statistically significant relationship between the presence of class I integrons, CTX-M and fim genes in UPECs (30). In our study, there was no significant correlation between the presence of integrons and virulence genes.

Another issue about UPEC strains is to clarify the relationship of their virulence factors with phylogenetic distributions. Ochoa et al. concluded that most of the MDR-UPEC strains were grouped in D (55\%) and B2 (39\%) and the most frequent virulence genes in these groups were several fimbrial genes (ecpA, fimH, csgA, and papGII), an iron uptake gene (chuA) and a toxin gene (hlyA) (7). Similarly, in South Korea, Lee et al. indicated that most of the virulence genes (fimH, sfa, pap, sfa, hly, feoB, irp2, $\operatorname{iro} N$ ) were found to be significantly higher in the strains grouped as B2 and D (31). Yılmaz and Aslantaş from Turkey showed that $E$. coli strains isolated from urine were mostly shown to be defined as group B2 3 (36\%) and group A1 (21\%); most strains were reported to carry at least one virulence gene (32). In line with other research, 
we found that PAI $(p<0.001)$, ompT $(p=0.035)$, and usp $(p<0.001)$ genes were significantly related to group B2 while only the ompT gene was significantly related to group $E(p=0.013)$.

In conclusion, unlike previous studies, we investigated the prevalence of integrons on genomic and plasmid DNAs separately. We have shown that they were more prevalent on plasmids (class I integron 68\%, class II integron $38 \%$ ) which highlights the common occurrence of horizontally transferring. To our knowledge, this is the first report detecting the presence of class III integron in UPEC strains isolated in Turkey and other countries from Europe. According to our results, the presence of integrons was found to be related neither to virulence genes nor phylogroups; however, the presence of PAl, ompT, and usp genes was found to be significantly related to phylogroups B2 and E.

Informed Consent: Written consent was obtained from the participants.

Ethics Committee Approval: This study was approved by the Istanbul Yeni Yüzyıl University Medical Faculty Research Ethics Committee (Date: 01.10.2018, No: 8).

Peer Review: Externally peer-reviewed.

Author Contributions: Conception/Design of Study- D.G., F.K.Y., M.K.; Data Acquisition- D.G., F.K.Y., D.C., M.O.; Data Analysis/Interpretation- D.G., F.K.Y., D.C., C.M.; Drafting Manuscript- D.G., F.K.Y., M.K.; Critical Revision of Manuscript- D.G., F.K.Y., M.K.; Approval and Accountability- D.G., F.K.Y., F.D.C., M.O., A.C.M., M.A.K.

Conflict of Interest: Authors declared no conflict of interest

Financial Disclosure: This study was supported by The Scientific and Technological Research Council of Turkey (TUBITAK) (Project No: 2209-a/2019).

\section{REFERENCES}

1. Azam H, Ghezeljeh SM, Mahmoud S. Prevalence of class 1 and 2 integrons among the multidrug resistant uropathogenic strains of Escherichia coli. Asian Biomed 2017;9(1):49-54. [CrossRef]

2. Ebrahim-Saraie HS, Nezhad NZ, Heidari H, Motamedifar A, Motamedifar M. Detection of antimicrobial susceptibility and integrons among extended-spectrum ß-lactamase producing uropathogenic Escherichia coli isolates in Southwestern Iran. Oman Medical J 2018;33(3):218-23. [CrossRef]

3. Yekani M, Memar MY, Baghi HB, Sefidan FY, Alizadeh N, Ghotaslou R. Association of integrons with multidrugresistant isolates among phylogenic groups of uropathogenic Escherichia coli. Microbiol Res 2018;9(1):10-3. [CrossRef]

4. El-Najjar N, Farah MJ, Hashwa FA, Tokajian ST. Antibiotic resistance patterns and sequencing of class I integron from uropathogenic Escherichia coli in Lebanon. Lett App Microbiol 2010;51(4):456-61. [CrossRef]
5. Khoramrooz SS, Sharifi A, Yazdanpanah M, Hosseini SAAM, Emaneini M, Gharibpour F et al. High frequency of class 1 integrons in Escherichia coli isolated from patients with urinary tract infections in Yasuj, Iran. Iranian Red Crescent Med Journal 2016;18(1):1-6. [CrossRef]

6. Poey ME, Laviña M. Integrons in uropathogenic Escherichia coli and their relationship with phylogeny and virulence. Microbiol Patho 2014;77:73-7. [CrossRef]

7. Ochoa SA, Cruz-Córdova A, Luna-Pineda VM, ReyesGrajeda JP, Cázares-Domínguez V, Escalona G, et al. Multidrug-and extensively drug-resistant uropathogenic Escherichia coli clinical strains: phylogenetic groups widely associated with integrons maintain high genetic diversity. Front in Microbiol 2016;7(2042):1-12. [CrossRef]

8. Partridge SR, Tsafnat G, Coiera E, Iredell JR. Gene cassettes and cassette arrays in mobile resistance integrons. FEMS Microbiol Rev 2009;33(4):757-84. [CrossRef]

9. Oliveira-Pinto C, Diamantino C, Oliveira PL, Reis MP, Costa PS, Paiva MC et al. Occurrence and characterization of class 1 integrons in Escherichia coli from healthy individuals and those with urinary infection. J Med Microbiol 2017;66(5):57783. [CrossRef]

10. Falakian Z, Nikokar I, Nafisi MR, Karimi A, Validi M. Frequency of class 1 integrons among Escherichia coli isolates of patients with urinary tract infection. Arch of Clin Infect Dis 2012;6(4):1-4.

11. Mandal P, Kapil A, Goswami K, Das B, Dwivedi SN. Uropathogenic Escherichia coli causing urinary tract infections. Indian J Med Res 2001;114:207-11.

12. Puente JL, Brettfinlay B. Pathogenic E. coli. In Groisman EA (ed) Principles of Bacterial Pathogenesis. California: Academic Press, 2001;388-428.

13. Yamamoto S. Molecular epidemiology of uropathogenic Escherichia coli. J Infect Chemother 2007;13:68-73. [CrossRef]

14. Miyazaki J, Ba-Thein W, Kumao T, Obata Yasuoka M, Akaza $\mathrm{H}$, Hayshi $\mathrm{H}$. Type 1, P and S fimbriae, and afimbrial adhesin I are not essential for uropathogenic Escherichia coli to adhere to and invade bladder epithelial cells. FEMS Immunol Med Microbiol 2002;25:23-6. [CrossRef]

15. Uzun $C$, Oncül $O$, Gümüş D, Alan $S$, Dayioğlu N, Küçüker MA. Virulence genes and antibiotic susceptibilities of uropathogenic E. coli strains. Clin Lab 2015;61(8):941-50. [CrossRef]

16. Nougayrède JP, Fernandes PJ, Donnenberg MS. Adhesion of enteropathogenic Escherichia coli to host cells. Cell Microbiol 2003;5:359-72. [CrossRef]

17. Clermont O, Bonacorsi S, Bingen E. Rapid and simple determination of the Escherichia coli phylogenetic group. Applied Environ Microbiol 2000;66(10):4555-8. [CrossRef]

18. Clermont O, Christenson JK, Denamur E, Gordon DM. The Clermont Escherichia coli phylo-typing method revisited: improvement of specificity and detection of new phylogroups. Environ Microbiol Reports 2013;5(1):58-65. [CrossRef]

19. Khairy RM, Mohamed ES, Abdel Ghany HM, Abdelrahim SS. Phylogenic classification and virulence genes profiles of uropathogenic E. coli and diarrheagenic E. coli strains isolated from community acquired infections. PLoS One 2019;14(9):1-10. [CrossRef]

20. Ren $C$, Zhao $Y$, Shen $Y$. Analysis of the effect of integrons on drug-resistant Staphylococcus aureus by multiplex PCR detection. Molecular Med Reports 2013;7(3):719-24. [CrossRef] 
21. Goldstein C, Lee MD, Sanchez S, Hudson C, Phillips B, Register B, et al. Incidence of class 1 and 2 integrases in clinical and commensal bacteria from livestock, companion animals, and exotics. Antimicrob Agents Chemother 2001;45(3):723-6. [CrossRef]

22. Farshad S, Japoni A, Hosseini M. Low distribution of integrons among multidrug resistant $E$. coli strains isolated from children with community-acquired urinary tract infections in Shiraz, Iran. Pol J Microbiol 2008;57(3):193-8.

23. Mirnezami M, Ranjbar R, Niakan M, Ahmadi MH. Frequency of antimicrobial resistance and class 1 and 2 integrons in Escherichia coli strains isolated from urinary tract infections. Iran J Pharma Res 2020;19(3):282-7.

24. Al-Assil B, Mahfoud M, Hamzeh AR. First report on class 1 integrons and Trimethoprim-resistance genes from dfrA group in uropathogenic E. coli (UPEC) from the Aleppo area in Syria. Mob Gen Elements 2013;3(3):1-6. [CrossRef]

25. Solberg OD, Ajiboye RM, Riley LW. Origin of class 1 and 2 integrons and gene cassettes in a population-based sample of uropathogenic Escherichia coli. J Clin Microbiol 2006;44(4):1347-51. [CrossRef]

26. Zeighami H, Haghi F, Masumian N, Hemmati F, Samei A, Naderi G. Distribution of integrons and gene cassettes among uropathogenic and diarrheagenic Escherichia coli isolates in Iran. Microb Drug Resist 2015;21(4):435-40. [CrossRef]

27. Halaji M, Feizi A, Mirzaei A, Sedigh Ebrahim-Saraie $H$, Fayyazi A, Ashraf A, et al. The Global Prevalence of Class 1 Integron and associated antibiotic resistance in Escherichia coli from patients with urinary tract infections, a systematic review and Meta-Analysis. Microb Drug Resist 2020;26(10):1208-18. [CrossRef]
28. Çopur ÇA, Sandallı C, Budak EE, Yağmur G, Cizmeci Z, Ak $S$, et al. Characterization of class 1 and class 2 integron gene cassettes in Escherichia colistrains isolated from urine cultures: a multicenter study. Mikrobiyol Bult 2016;50(2):17585. [CrossRef]

29. Gündoğdu A, Long YB, Vollmerhausen TL, Katouli $M$. Antimicrobial resistance and distribution of sul genes and integron-associated intl genes among uropathogenic Escherichia coli in Queensland, Australia. J Med Microbiol 2011;60(11):1633-42. [CrossRef]

30. Düzgün AÖ, Okumuş $F$, Saral $A$, Çiçek $A C ̧$, Cinemre $S$, Determination of antibiotic resistance genes and virulence factors in Escherichia coli isolated from Turkish patients with urinary tract infection. Revista da Sociedade Brasileira de Medi Tropic 2019;52:1-5. [CrossRef]

31. Lee JH, Subhadra B, Son YJ, Kim DH, Park HS, Kim JM, et al. Phylogenetic group distributions, virulence factors and antimicrobial resistance properties of uropathogenic Escherichia coli strains isolated from patients with urinary tract infections in South Korea. Lett App Microbiol 2016;62(1):84-90. [CrossRef]

32. Yılmaz EŞ, Aslantaş Ö. Phylogenetic group/subgroups distributions, virulence factors, and antimicrobial susceptibility of Escherichia coli strains from urinary tract infections in Hatay. Revista da Sociedade Brasileira de Medi Tropic 2020;53:1-6. [CrossRef] 